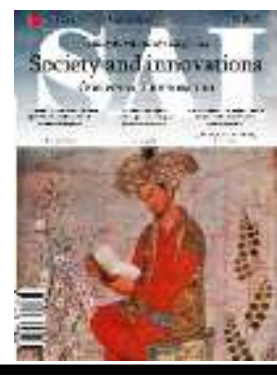

\title{
Patients with chronic liver disease and COVID-19 (literature review and own data)
}

\author{
Yuldasheva D.H ${ }^{1}$ Muxamedova Z.X. ${ }^{2}$ Shadjanova N.S. ${ }^{3}$ \\ Bukhara state medical institute
}

\begin{tabular}{l} 
ARTICLE INFO \\
\hline Article history: \\
Received January 2021 \\
Received in revised form \\
15 January 2021 \\
Accepted 20 February 2021 \\
Available online \\
7 March 2021 \\
\\
\hline Keywords: \\
COVID 19 \\
Liver damage \\
Prognosis \\
Chronic liver disease \\
Blood chemistry \\
The course of a new \\
coronavirus infection
\end{tabular}

ABSTRACT

The pandemic of the new coronavirus COVID-19 has switched medicine around the world on the primary fight against this infection. Patients with chronic liver diseases require increased attention of doctors during an epidemic, since against the background of an exacerbation of their disease, not only the risk of contracting the COVID-19 viral infection increases, but also its more severe course. Patients with confirmed COVID-19 with severe liver damage - high biochemical activity. According to some reports, patients with a severe course of COVID-19 have an increase in ALT levels, a decrease in the number of platelets, a decrease in the level of albumin, and a connection (although not all indicators) with a higher risk of mortality is possible.

2181-1415/CC 2021 in Science LLC.

This is an open access article under the Attribution 4.0 International (CC BY 4.0) license (https://creativecommons.org/licenses/by/4.0/deed.ru)

\section{Jigarning surunkali kasalligi va COVID-19 bilan kasallangan bemorlar (adabiyotlarni ko'rib chiqish va o'z ma'lumotlari)}

Калит сўзлар:
COVID 19
Jigar shikastlanishi
Prognoz
Jigarning surunkali kasalligi
Qon kimyosi
Yangi koronavirus
infektsiyasining borishi

\section{АННОТАЦИЯ}

COVID-19 yangi koronavirusining pandemiyasi butun dunyoda tibbiyotni ushbu infektsiyaga qarshi asosiy kurashga o'zgartirdi. Surunkali jigar kasalliklariga chalingan bemorlar epidemiya paytida shifokorlarning diqqatini kuchaytirilishini talab qiladi, chunki ularning kasalliklari kuchayishi fonida nafaqat COVID-19 virusli infektsiyasini yuqtirish xavfi, balki uning og'ir yo'li ham oshadi. Jigarning jiddiy shikastlanishi bilan tasdiqlangan KOVID-19 bilan kasallangan bemorlar - yuqori biokimyoviy faollik. Ba'zi xabarlarga ko'ra, KOVID-19 ning og'ir kursi bilan og'rigan bemorlarda ALT darajasi oshadi,

\footnotetext{
${ }^{1}$ Bukhara state medical institute. Bukhara. Uzbekistan

2 Bukhara state medical institute. Bukhara. Uzbekistan

${ }^{3}$ Bukhara state medical institute. Bukhara. Uzbekistan
} 
trombotsitlar soni kamayadi, albuminlar miqdori kamayadi va yuqori xavfga ega bo'lgan ulanish (barcha ko'rsatkichlar emas). o'lim mumkin.

\section{Пациенты с хроническим заболеванием печени и COVID-19 (обзор литературы и собственные данные)}

\begin{tabular}{l}
\hline Ключевые слова: \\
COVID 19 \\
Поражение печени \\
Прогноз \\
Хроническое заболевание \\
печени \\
Химический анализ крови \\
Течение новой \\
коронавирусной \\
инфекции
\end{tabular}

\begin{abstract}
АННОТАЦИЯ
Пандемия нового коронавируса COVID-19 переключила медицину во всем мире на первичную борьбу с этой инфекцией. Пациенты с хроническими заболеваниями печени требуют повышенного внимания врачей во время эпидемии, поскольку на фоне обострения их заболевания увеличивается не только риск заражения вирусной инфекцией COVID 19, но и более тяжелое ее течение. Пациенты с подтвержденным COVID-19 с тяжелым поражением печени - высокая биохимическая активность. По некоторым данным, у пациентов с тяжелым течением COVID-19 наблюдается повышение уровня АЛT, снижение количества тромбоцитов, снижение уровня альбумина и связь (хотя и не все показатели) с более высоким риском смертности возможна.
\end{abstract}

\section{THE URGENCY OF THE PROBLEM}

The global pandemic of the new coronavirus infection (COVID-19) caused by the SARSCoV-2 coronavirus began in Wuhan, China in December 2019 and has since spread around the world. Coronavirus infection (COVID-19) is an acute infectious disease caused by a new strain of the SARS CoV-2 coronavirus with aerosol-capillary and contactmechanical transmission [2,4,17]. The pathogenetic COVID-19 is characterized by viremia, local and systemic immune-inflammatory processes, hyperactivity of the coagulation cascade, endothelial disease, hypoxia, which leads to the development of micro- and macrothrombosis; proceeds from asymptomatic to clinically severe forms with intoxication, fever, damage to the vascular endothelium, lungs, heart, kidneys, gastrointestinal tract, central and peripheral nervous system, system at risk $[1,2,3,5,7,9,18,21]$.

The pandemic of the new coronavirus COVID-19 has switched medicine around the world on the primary fight against this infection. However, the COVID-19 attack did not cancel diseases that humanity suffered before the pandemic developed. And, as thanks to the joint efforts of the medical community, the pandemic is stabilizing, and in a number of countries are beginning to decline, the need is ripe to return attention to patients with other diseases and assess their interaction with the new an unprecedented infection, the features of which both per se and in combination with other pathological conditions, we still know very little $[3,4,6,18]$.

During the pandemic, it became clear that COVID - 19 is not just acute respiratory infection, but a disease with multiple organ systemic damage, including number of such an important organ as the liver. This issue was covered by us in special reviews $[3,5,6,13,15]$ based on a generalization of the data available at that time literature. The liver is a vital 
organ with multiple functions. The protective function of the liver includes detoxification of endogenous and exogenous factors. Liver cells are actively involved in the body's immune defense. The liver contains T- and B-lymphocytes, endothelial cells produce inflammatory mediators IL-1 and IL-6, Kupffer cells are specialized liver macrophages and are necessary for effective capture of the virus and disruption of its replication. The latter process includes an asset cation of Kupffer cells with interferon (IFN) -I and prevents the spread of the virus to neighboring hepatocytes. In the absence of Kupffer cells, hepatocytes are unable to suppress viral replication even in the presence of IFN-I, which leads to longterm viral replication and even to possible severe T-cell immunopathology $[4,18,20]$. It has been shown that the liver, along with the respiratory tract, is actively participates in the pathological process, and the course and outcome of COVID-19 are closely related to the frequency and extent of liver damage from this infection.

However, the problems of patients with chronic liver disease (ChLD) amid the COVID-19 pandemic remain unresolved and require study. Chronic liver diseases are among the most common in the world, and in an epidemic, effective follow-up and continued treatment of patients with these pathologies is especially important to maintain health, as well as to reduce the burden on health care and reduce the total number of victims of coronavirus infection. To date, scientific data have confirmed that the risk group with an increased likelihood of infection and a severe course of coronavirus infection includes elderly patients and patients with chronic cardiovascular diseases, such as hypertension, coronary heart disease and diabetes mellitus. Less is known about the effects of other chronic diseases, in particular liver disease. However, it is already clear that patients with severe fibrosis and cirrhosis of the liver, patients after liver transplantation are also a vulnerable group with an increased risk of infection and severe course of COVID-19. Therefore, they are strictly prescribed self-isolation and reduction of social contacts $[3,5,7]$.

The liver is a vital organ with multiple functions. The protective function of the liver includes detoxification of endogenous and exogenous factors [1,5,7,26,27].

Analysis of clinical data the picture of the new coronavirus infection COVID-19 shows that liver dysfunction is common a phenomenon in hospitalized patients with severe disease. Elevated levels alanine aminotransferase (ALT) and aspartate aminotransferase (AST) were registered, according to different data, in 16-53\% of patients $[4,8,10,17,22]$. Liver dysfunction in COVID-19 is considered mild by most researchers and is seen as a concomitant damage $[4,10,20]$. Some data indicate that $2-11 \%$ of patients with COVID-19 had comorbidities liver, and in 14-53\% of cases, there were abnormal aminotransferase levels during disease progression. Patients with severe COVID-19 appear to more often suffer from liver dysfunction. In a study conducted in New York with the participation of 5700 patients, 58.4\% had AST values above $40 \mathrm{U} / \mathrm{L}$ and $39.0 \%$ had ALT values above $60 \mathrm{U} / \mathrm{L}$. In the same cohort, 56 (2.1\%) patients developed acute liver injury, defined as an increase in AST or ALT levels by more than 15 times compared with the upper limit of normal. Of these 56 patients, 3 were 18-65 years old $(3 / 1373 ; 0.2 \%)$ and were subsequently discharged, and 53 died: 25 were $18-65$ years old $(25 / 134 ; 18.7 \%)$, and 28 were over 65 years old $(28 / 469 ; 6.7 \%)$. Analysis of the data shows that the incidence of liver dysfunction increases in proportion to the severity of COVID-19. Apparently, in COVID-19, elevated ALT, hypoalbuminemia, and thrombocytopenia are an unfavorable prognosis factor for the disease. Similar findings 
have been reported in pediatric practice. Few studies of infants with COVID-19 suggest liver damage against the background of disease progression from the 7 th to the 11 th day of the disease, along with multiple lesions other organs $[4,14,18]$. Investigations of the hepatic ducts affected in patients with COVID-19, have shown their high susceptibility to infection COVID-19 and maintaining robust viral replication. Virus SARS-CoV-2 impairs the barrier and transport functions of bile acids in cholangiocytes $[4,22]$. This assumption is supported by an increase in circulating serum gamma-glutamyl transferase (GGT) levels in patients with COVID-19. Most patients with severe COVID-19 there is an abnormal increase in serum proinflammatory cytokines. Overproduction proinflammatory cytokines (tumor necrosis factor, IL-6, IL-2, IL-7, inducible interferon- $\gamma$ protein 10, monocytic chemoattractant protein 1 , macrophage inflammatory protein 1- $\alpha$ and IL-11) has been described as a cytokine storm leading to increased risk of vascular hyperpermeability, multiple organ failure, and ultimately death when high cytokine concentrations do not diminish over time $[4,11]$. Activation of blood clotting pathways during the immune response to infection leads to excess production of pro-inflammatory cytokines, which leads to multi-organ damage. During inflammation, the concentration of anticoagulants decreased due to a decrease production and increased consumption. This procoagulant-anticoagulant imbalance predisposes to the development of microthrombosis, disseminated intravascular blood coagulation and multiple organ failure $[4,12,26]$. Patients with chronic liver diseases require increased attention of doctors during an epidemic, since against the background of an exacerbation of their disease, not only the risk of contracting the COVID-19 viral infection increases, but also its more severe course.

Current research has shown that the poor prognosis in COVID-19 patients was related to gender (male), age (over 60 years), underlying medical conditions (diabetes, cardiovascular disease), secondary ARDS, and other related factors. However, ALT, AST, total bilirubin and other liver function indicators were significantly increased in patients with severe COVID-19 compared with patients with mild COVID-19, and indicators of function liver functions gradually returned to normal in the course of recovery. Liver damage in patients with mild COVID-19 is often temporary and can be restored to normal without any specific treatment. Hepatoprotective drugs have usually been given to patients with severe liver damage. In addition, liver dysfunction in COVID-19 patients has been associated with activation of coagulation and fibrinolysis, relatively low platelet count, increased granulocyte count and neutrophil-to-lymphocyte ratio, and high ferritin levels. Although these parameters were considered non-specific markers of inflammation, they also corresponded to the dysregulation of innate immunity. It is worth noting that these changes immune balance occurred with increasing age of the patient. So the situation could be worse for elderly patients. The effect of glucocorticoids on the prognosis of COVID-19 in patients with autoimmune hepatitis is unknown. Severe COVID-19 patients require more intensive monitoring or individualized treatment, especially in older patients with other osfalsehoods $[19,24,25]$.

\section{CONCLUSION}

Patients with chronic liver diseases require increased attention of doctors during an epidemic, since against the background of an exacerbation of their disease, not only the risk of contracting the COVID-19 viral infection increases, but also its more severe course. 
Previous studies show that patients with coronavirus infection (COVID-19) often have elevated liver enzyme levels, while other studies have shown that chronic liver disease is a risk factor for severe infection and increased mortality.

\section{REFERENCES}

1. Ильченко Л.Ю., Никитин И.Г., Федоров И.Г. COVID-19 и поражение печени. Архив внутренней медицины. 2020;10(3):188197. https://doi.org/10.20514/2226-6704-2020-10-3-188-197.

2. Маев И.В., Бордин Д.С. Ведение пациентов с хроническими заболеваниями печени в условиях пандемии COVID-19 // Методические рекомендации // Москва 2020. - стр- 28.

3. Маннанова И. В., Понежева Ж. Б., Макашова В. В., Омарова Х. Г., Рейзис А. Р.,Горелов А. В. 2020. некоторые аспекты повреждения печени при инфекции, вызванной sars-cov-2. COVID-19 preprints.microbe.ru.https://doi.org/10.21055/preprints-3111776

4. Пинчук Т. В., Орлова Н. В., Суранова Т. Г., Бонкало Т. И. Механизмы поражения печени при COVID 19. Медицинский алфавит. 2020; (19): 39-46. https://doi.org/10.33667/2078-5631-2020-19-39-46.

5. Рейзис А. Р., Понежева Ж. Б., Макашова В. В., Омарова Х. Г., Маннанова И. В., Горелов А. В. 2020. Поражение печени при COVID-19. Covid19-preprints.microbe.RU. https://doi.org/10.21055/preprints-3111760

6. Рейзис А. Р., Понежева Ж. Б., Макашова В. В., Омарова Х. Г., Маннанова И. В., Горелов А. В. 2020. Хронические заболевания печени в период пандемии COVID - 19. Россия.2020. - стр.-1-7.

7. Akdur A, Karakaya E, Ayvazoglu Soy EH, et al. Coronavirus Disease (COVID-19) in Kidney and Liver Transplant Patients: A Single-Center Experience. Exp Clin Transplant. 2020;18(3):270-274. doi:10.6002/ect.2020.0193

8. APASL Covid-19 Task Force, Lau G, Sharma M. Clinical practice guidance for hepatology and liver transplant providers during the COVID-19 pandemic: APASL expert panel consensus recommendations. Hepatol Int. 2020 Jul; 14 (4): 415-428. DOI: 10.1007/s12072-020-10054-w.

9. Artru F, Alberio L, Moradpour D, Stalder G. Acute immune thrombocytopaenic purpura in a patient with COVID-19 and decompensated cirrhosis. BMJ Case Rep. 2020;13(7):e236815. Published 2020 Jul 7. doi:10.1136/bcr-2020-236815

10. Bangash M. N.; Patel J.; Parekh D. COVID-19 and the liver: Little cause for concern. Lancet Gastroenterol. Hepatol. 2020, 5, 529-530. DOI: 10.1016/S 24681253(20)30084-4.

11. Jose RJ, Manuel A. COVID-19 cytokine storm: the interplay between nflammation and coagulation. Lancet Respir Med. 2020. https://doi. org/10.1016/S 22132600(20),30216-2.

12. Tang N, Li D, Wang X, Sun Z. Abnormal coagulation parameters are associated with poor prognosis in patients with novel coronavirus pneumonia. J Thromb Haemost. 2020; 18: 844-7. DOI: 10.1111/jth.14768.

13. Chau TN, Lee KC, Yao H, Tsang TY, Chow TC, et al. SARS-associated viral hepatitis caused by a novel coronavirus: report of three cases. Hepatology. 2004; 39: 302-310. DOI: 10.1002/hep.20111. 
14. Cui Y, Tian M, Huang D, Wang X, Huang Y, et al. A 55-Day-Old Female Infant Infected With 2019 Novel Coronavirus Disease: Presenting With Pneumonia, Liver Injury, and Heart Damage. J Infect Dis. 2020 May 11; 221 (11): 1775-1781. D0I: 10.1093/infdis/jiaa113.

15. Dahlqvist G, Ciccarelli O, Van Vlierberghe H, et al. Liver transplantation during the COVID-19 epidemic: recommendations from the Belgian Liver Intestine Transplant Committee (BeLIAC). Acta Gastroenterol Belg. 2020;83(2):340-343

doi:10.3748/wjg.v26.i22.29878

16. El Kassas M, Alboraie M, Al Balakosy A, et al. Liver transplantation in the era of COVID-19. Arab J Gastroenterol. 2020;21(2):69-75. doi:10.1016/j.ajg.2020.04.019

17. Ghayda RA, Lee J, Lee JY, Kim DK, Lee KH, et al. Correlations of Clinical and Laboratory Characteristics of COVID-19: A Systematic Review and Meta-Analysis. Int J Environ Res Public Health. 202017 (14): 5026. DOI: 10.3390/ijerph17145026.

18. Lang PA, Recher M, Honke N, Scheu S, Borkens S, et al. Tissue macrophages suppress viral replication and prevent severe immunopathology in an interferon-Idependent manner in mice. Hepatology. 2010 Jul; 52 (1): 25-32. DOI: 10.1002/ hep.23640.

19.Musa S. Hepatic and gastrointestinal involvement in coronavirus disease 2019 (COVID-19): What do we know till now? Arab J Gastroenterol. 2020; 21: 3-8.

20. Polakos NK, Cornejo JC, Murray DA, Wright KO, Treanor JJ, Crispe IN, et al. Kupffer cell dependent hepatitis occurs during influenza infection. Am J Pathol. 2006; 168 (4): 1169-78.

21.Sarin SK, Choudhury A, Lau GK, et al. Pre-existing liver disease is associated with poor outcome in patients with SARS CoV2 infection; The APCOLIS Study (APASL COVID-19 Liver Injury Spectrum Study) [published online ahead of print, 2020 Jul 4]. Hepatol Int. 2020;1- 11. doi:10.1007/s12072-020-10072-8

22. Zhang C.; Shi L.; Wang F. S. Liver injury in COVID-19: Management and challenges. Lancet Gastroenterol. Hepatol. 2020, 5, 428-430. DOI: 10.1016/S 24681253(20)30057-1.

23. Zhao B, Ni C, Gao R, Wang Y, Yang L, Wei J, et al. Recapitulation of SARS-CoV-2 infection and cholangiocyte damage with human liver ductal organoids. Protein Cell. 2020. Oct; 11 (10): 771-775. https://doi.org/10.1007/s13238-020-00718-6

24. Wu J, Song S, Cao HC, Li LJ. Liver diseases in COVID-19: Etiology, treatment and prognosis. World J Gastroenterol. 2020; 26 (19): 2286-2293. DOI: 10.3748/wjg.v26.i19.2286.

25. $\mathrm{Wu}$ J. et al. Liver diseases in COVID-19: Etiology, treatment and prognosis //World Journal of Gastroenterology. 2020. T. 26. N 19. C. 2286. DOI: 10.3748/wjg.v26.i19.2286.

26. Yuldasheva D.H. Shadjanova N.S., Oltiboyev R.O. Non-alcoholic fatty liver disease and modern medicine // Academicia an international multidisciplinary research journal // Vol.10. Issue 11. Nov.2020. - P. 1931 - 1937.

27. Yuldasheva D.H., Zokirov V.Z., G’ulomova Sh.Q. Non-alcoholic fatty liver disease: Modern view of the problem // A Multidisciplinary Peer Reviewed Journal.Vol.6. Issue 12. Dec.2020. - P. 286 - 292. 